\title{
Design and Development of Business English Major Practical Skill Education
}

\author{
Wang Shanshan ${ }^{1, a,{ }^{*}}$, Zhang Lina ${ }^{2, b}$ \\ 1 Dalian Neusoft University of Information, Dalian, Liaoning, China \\ 2 Dalian Neusoft University of Information, Dalian, Liaoning, China \\ awangshanshan@neusoft.edu.cn, bzhanglina@neusoft.edu.cn \\ ${ }^{*}$ Corresponding author: Wang Shanshan
}

Keywords: Business English Major, Practical Skill Education, Project.

\begin{abstract}
Business English Major practical skill education is of importance for both the development of export-oriented economy and international trade of companies. Traditional Business English major talent cultivation curriculum neglects the inner relation between courses and significance of real practice. DNUI English Department has designed and developed a new Business English Major practical skill education system which observe the inner connection between courses and has made good effects. With this paper, the author wishes to present a new way of teaching Business English Major practical skill.
\end{abstract}

\section{Introduction}

With the expanding of Belt and Road Initiative, Language plays a more and more important role in breaking cultural barrier and serving business. There is a growing demand for Business English Majors who possess excellent English proficiency, business knowledge and cross-cultural communication skills. Export-oriented economy in the new era raised higher and urgent requirement on both the quality and quantity of Business English talent cultivation. Unfortunately, current higher education could not fully satisfy this increasing need.

In a survey made by Dalian Neusoft University of Information (hereinafter referred to as DNUI), most participated companies claimed that they need their employees with Business English academic background possess language proficiency, business practical skill and cross-cultural communication skills at certain level. While the survey also shows that universities in China seldom design and develop Business English Major practical skill education beyond the boundary of courses which in fact cut the inner relation between courses, which resulted in the separation between courses.

\section{Business English Major Practical Skill Education System of DUNI}

In order to cultivate the satisfying Business English majors, DNUI English Department made a survey among interest-related parties including enterprises, other universities, graduates and parents. With the help of survey data, DNUI English Department figured out the overall conditions a Business English major should reach. Then, DNUI English Department made an analysis on the "national higher education standard" issued by the Education Ministry of China. Based on the analysis, DNUI English Department set up a capability framework for its graduates. To make sure all its graduates could fits that requirement, DNUI English Department started to make a match between courses and capability framework and tried to examine the teaching effectiveness through projects at various levels. 
Table 1. Project System of Business English Major

\begin{tabular}{|l|l|}
\hline No. & Project level \\
\hline P5 & Level 5: Unit Project, a project based on the knowledge and skill of a unit \\
\hline P4 & Level 4: Unit Group Project, a project based on the knowledge and skill of a unit group \\
\hline P3 & Level 3: Course Project, a project based on the knowledge and skill of a course \\
\hline P2 & $\begin{array}{l}\text { Level 2: Course Group Project, a project based on the knowledge and skill of a course } \\
\text { group }\end{array}$ \\
\hline P1 & Level 1: Major Project, a project based on the knowledge and skill of all key courses \\
\hline
\end{tabular}

Then, the Business English Major curriculum could be illustrated with the following fish-bone chart.

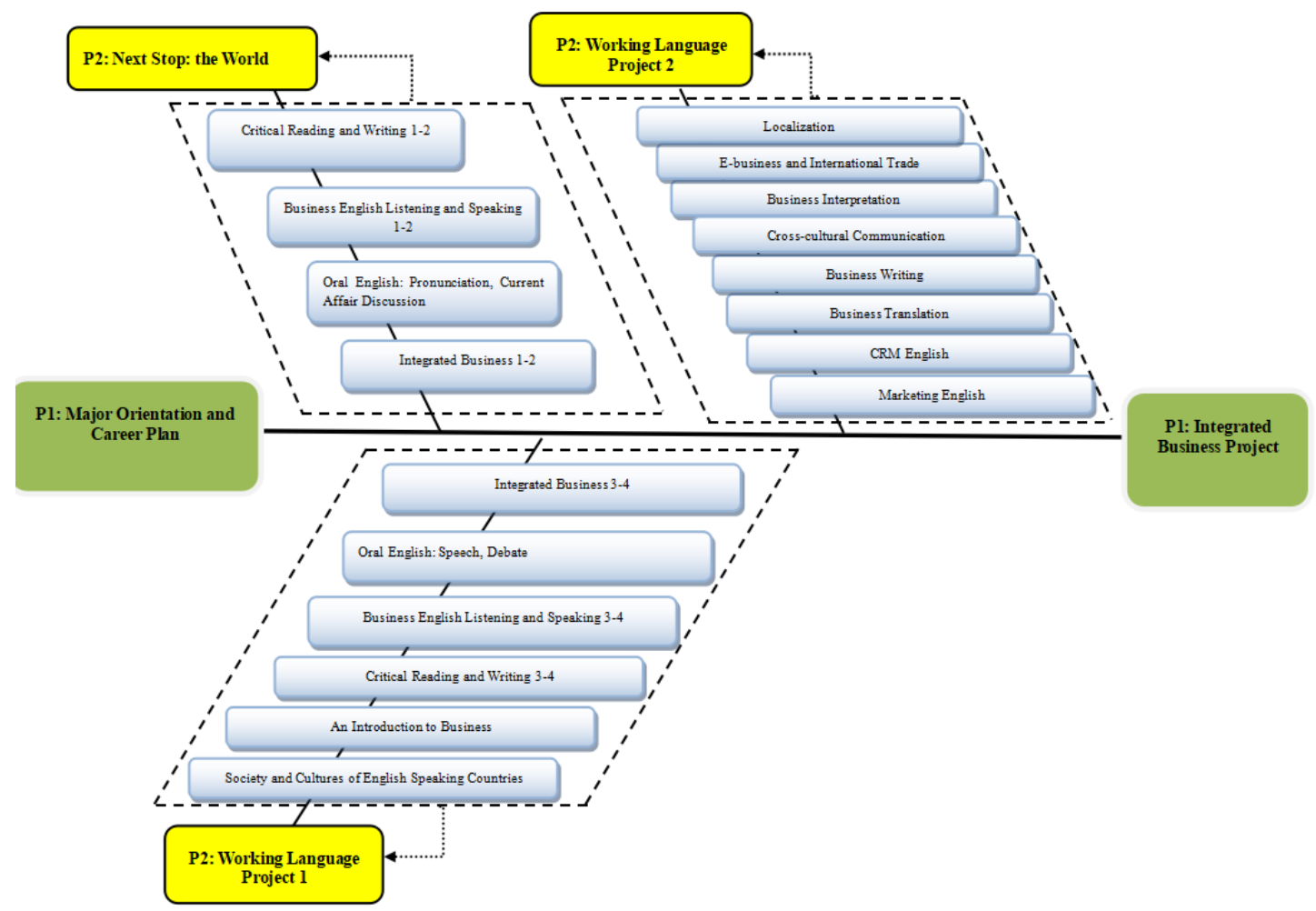

Chart 1. Fish-bone Chart of Business English Major curriculum

\section{Development of Business English Major Practical Skill Education System}

The designing job of P3-P5 is relatively easier compared that of P1-P2. Teachers can have a clear idea by narrowing down the course teaching target, unit group teaching target and unit teaching target. By establish a definite and quantity target of each unit, unit group or course, the teachers can have a clearer map on the relations within teaching content and design proper project to examine students' practical skills. In the past 5 years, DNUI English Department has made practical skill teaching materials for more than 80 courses ( P3-P5), including textbooks, syllabus, teaching plans, course wares, and course websites.

The P2 Series is made up of three level 2 projects: Next Stop: the World (Freshmen year) , Working Language Project 1 (Sophomore year) and Working Language Project 2 (Junior year) . Then, students are supposed to take level 1 project ( Integrated Business Project) and internship at companies.

By Next Stop: the World, students will enhance their English listening, speaking, reading and writing abilities and expand their international horizons and have a better understanding of English-speaking countries. Students are guided to make research on English-speaking countries' culture, custom and education.

By Working Language Project 1, students will simulate the major working procedures of marketing department, PR department, HR department and accounting department of a company. By this project, students could master the skills of oral and written communication in English, 
Business practice and cross-cultural communication.

By Working Language Project 2, students will experience the complete start-up procedures virtually, by making market survey, writing business plan, participation in VC conference. This project intends to cultivate students' start-up abilities and professional skills.

By Integrated Business Project, Students will simulate the procedure of expanding overseas market for their own start-up companies. It is a integrated training of what students have learned at college.

\section{Teaching Effects}

The Business English Major Practical Skill Education System has been applied to Business English Majors of DUNI for 4 rounds. Students commented it as a fresh and practical training program, and agreed that their English proficiency was improved by reading and collecting materials, and their business practical skills and cross-cultural communication skills were better through simulation and real case analyses.

In addition, students achieved excellent scores in academic competitions. In the past four years, they won more than 20 national prizes and over 50 provincial prizes.

\section{Conclusion}

The Business English major Practical Skill Education system of DNUI English Department still has great room to improve itself. During the procedure of design and development of this system, DNUI English Department have found the update of real cases from companies and the perfection of simulation environment contribute greatly in the teaching effects. DNUI English Department wish this paper could offer some references to teachers who are interested in business English major practical skill education.

\section{References}

[1] Li Guibo, Business English Practice Course System Forming of Application-Oriented Universities Based on Constructivism, Journal of Anshun University, vol.17, pp. 70-71, 2015.

[2] He Hongli and Niu Guixia, Research on the Construction of Practice Teaching System for the Business English Majors in the Provincial University, Journal of Hebei University of Engineering(Social Science Edition), vol.33, pp. 111-113, 2016.

[3] Wang Lifei, Ye Xingguo and Yanming, Business English Practice Course System Construction of Application-Oriented Universities, English Square, vol.1, pp. 92-93, 2017.

[4] Zhang Jianying, The Cultivation of Practical Skills of Business English Majors under the Philosophy of CDIO--A Case Study of DNUI, Journal of Kaifeng Institute of Education, vol.37, pp. 80-81, 2017.

[5] Wang Yanyan, A Comparative Study of Business English Curricula, Heilongjiang Researches on Higher Education, vol.293, pp. 157-160, 2018. 